\title{
Detection of Avian Influenza Virus of H9 Subtype in the Faeces of Experimentally and Naturally Infected Chickens by Reverse Transcription-Polymerase Chain Reaction
}

\author{
H. NOROOZIAN ${ }^{1}$, M. VASFI MARANDI ${ }^{1}$, M. RAZAZIAN $^{2}$ \\ ${ }^{1}$ Department of Clinical Sciences, Faculty of Veterinary Medicine, University of Tehran, \\ Tehran-Iran \\ 2 Private Practitioner \\ Received January 8, 2007 \\ Accepted July 9, 2007
}

\begin{abstract}
Noroozian H., M. Vasfi Marandi, M. Razazian: Detection of Avian Influenza Virus of H9 Subtype in the Faeces of Experimentally and Naturally Infected Chickens by Reverse Transcription-Polymerase Chain Reaction. Acta Vet. Brno 2007, 76: 405-413.

Avian Influenza (AI) is a viral, highly contagious disease of domestic and wild birds. In an avian diagnostic laboratory, it is essential to have methods for rapid detection of respiratory viruses. In the present study, cloacal swabs collected from chickens experimentally and naturally infected with mild pathogenicity AI virus subtype H9, used in a reverse transcription-polymerase chain reaction (RTPCR) assay for detection of AI. On cloacal swabs collected from experimentally infected chickens, AI virus was detected most frequently between days 3 and 7 post infection (p.i.) and the relative sensitivity, specificity, correlation rate, positive predictive value and negative predictive value of the RT-PCR compared to virus isolation (VI) assay were $84 \%, 80 \%, 82 \%, 83 \%$ and $81 \%$, respectively. On pooled cloacal swabs collected from flocks suspected of AI, these results were $96 \%, 100 \%, 97 \%$, $83 \%$ and $100 \%$, respectively. The results proved that the RT-PCR assay could be a reliable and rapid alternative to VI assay for detection of AI virus subtype H9 in faecal specimens.
\end{abstract}

AI, RT-PCR, H9, cloacal swabs

Avian influenza (AI) is a viral, highly contagious disease of domestic and wild birds (Murphy et al. 1999). Influenza A viruses of subtype H9N2 are now considered to be widespread in poultry and have demonstrated the ability to infect humans (Fedorko et al. 2006; Liu et al. 2003; Swayne et al. 2003). In Iran, H9N2 subtype outbreaks have been frequently recorded since 1998 (Nili and Asasi 2003; Vasfi Marandi and Bozorgmehri Fard 1999).

Because mildly pathogenic AI infection in chickens does not cause any pathognomonic clinical sign, the presence of the infection should be determined by diagnostic tests (Spackman et al. 2002). In the diagnostic laboratory, it is essential to have methods for rapid diagnosis of avian respiratory viruses, particularly for the detection of viruses in early stages of the infection in clinical specimens (Cattoli et al. 2004).

Virus isolation (VI) is regarded as the "gold standard" among different methods for influenza virus detection (Allwinn et al. 2002; Booth et al. 2006; Gavin et al. 2003; OIE 2004). However, as a diagnostic method, VI has some important disadvantages. By this method, samples should be transferred quickly to the laboratory and processed immediately to avoid inactivation of the virus (Allwinn et al. 2002). Virus culture is laborious and results are generally available in four to five days and a definitive negative diagnosis may require culture for up to 2 weeks (Aldous and Alexander 2001; Cattoli et al. 2004; Gavin et al. 2003; Gohm et al. 2000). Therefore, the use of rapid, validated alternative 
tests for diagnosis of AI could be advisable (Cattoli et al. 2004). Serological methods can detect a suspected case of influenza; at least, 1 - 2 weeks post infection. Two pairs of sera samples should be collected during acute and convalescence periods of disease (Allwinn et al. 2002).

New rapid diagnostic kits for influenza can detect viral antigens within 10 - 30 min and do not require a viable virus and, therefore, are less prone to bad conditions of sample storage and transfer (Allwinn et al. 2002). But, overall, there are controversial results about the satisfactory sensitivity and specificity of these kits (Cattoli et al. 2004; Davison et al. 1998; Dominguez et al. 1993; Fedorko et al. 2006; Gavin et al. 2003; Hermann et al. 2001; Ryan-Poirier et al. 1992; Waner et al. 1991; Woolcock et al. 2005).

Reverse transcription-polymerase chain reaction (RT-PCR) technology is going to revolutionize influenza diagnosis and monitoring (Swayne et al. 2003). Compared to VI, sample homogenization, RNA extraction and RT-PCR could be completed within one day (Gohm et al. 2000) and this molecular technology reduces the handling of infectious materials (Spackman et al. 2002).

AI virus shedding in chicken faeces has been previously described (Swayne et al. 2003). The faeces are one of the most important sources of AI virus (OIE 2004). Virus detection in faeces allows the detection of AI in live domestic or wild birds. Particularly, in migratory birds, this could be an important tool for detection of latent AIV infection and epizootiological surveys.

The aim of this study was to set up a rapid, sensitive and specific RT-PCR assay for simultaneous detection and subtyping of AIV of H9 subtype in faecal specimens. The efficiency of this RT-PCR assay was compared with standard VI assay of AI virus in embryonated chicken eggs.

\section{Materials and Methods}

Faecal swabs sampling

Cotton swabs were used to prepare faecal samples from birds. Swabs were placed into tubes containing $1 \mathrm{ml}$ PBS solution (pH 7.2) and antibiotics (10.000 IU/ml penicillin, $1 \mathrm{mg} / \mathrm{ml}$ streptomycin sulphate, $1 \mathrm{mg} / \mathrm{ml}$ gentamicin sulphate, $20 \mathrm{IU} / \mathrm{ml}$ nystatin).

Experimental infection

Virus strain

Reference strain of A/chicken/Iran/ZMT-101/98 (H9N2) was used for experimental infection of chickens. Intravenous pathogenicity index (IVPI) of this field strain was 0.26 as mild pathogenic avian influenza (MPAI) virus (Vasfi Marandi and Bozorgmehri Fard 2001).

Chickens

Twenty four-week-old commercial broiler chickens that had never been exposed to AI subtype H9 and had no antibodies to AI, were used in this experiment. The chickens were divided in two ten-bird groups including test and control groups.

Experimental design

Chickens of the test group were inoculated via oculo-nasal route with $0.2 \mathrm{ml}$ of infectious allantoic fluid containing $2 \times 10^{7.5} \mathrm{EID}_{50}$ of the applied virus strain diluted in sterile PBS solution (pH 7.2) (day 0 of the experiment). Faecal samples were obtained daily from chickens of the test and control groups until day 10 post infection (p.i.) and stored separately at $-70{ }^{\circ} \mathrm{C}$ for the following analysis. All of the faecal samples collected from chickens of the test group and those collected on days 0,5 and 10 p.i. from control group were used in VI and RT-PCR.

Haemagglutination test (HI)

Blood samples were collected on the pre-inoculation, $7^{\text {th }}$ and $14^{\text {th }}$ days p.i. from all chickens and sera were tested against specific antibodies to $\mathrm{H} 9$ antigen by using HI-test, according to the manual of standards for diagnostic tests (OIE 2004).

Field samples

Faecal samples were collected from 30 flocks submitted to the poultry diagnostic laboratory of the Faculty of Veterinary Medicine that were suspected of being infected by AI. Cloacal swabs collected from a flock were pooled and stored separately at $-70^{\circ} \mathrm{C}$ for the following analysis. 
Virus isolation (VI)

This was performed according to the standard method (Senne 1998). Briefly, a volume of $0.2 \mathrm{ml}$ of faecal samples prepared for virus isolation were inoculated into chorioallantoic sac of 9- to 11-day-old embryonated chicken eggs from healthy mycoplasma free raised chickens. Each sample was inoculated into three eggs and incubated at $37^{\circ} \mathrm{C}$ for up to 6 days. Eggs were candled daily and embryos dying within $24 \mathrm{~h}$ post inoculation were discarded. All other eggs with embryos dying were transferred to $4{ }^{\circ} \mathrm{C}$ for further testing. Chorioallantoic fluids (CAFs) were harvested, clarified by low speed centrifugation and tested for haemagglutinating activity (HA). All of the HA negative CAFs were inoculated for the second passage.

RT-PCR

RNA extraction

Viral RNA was extracted with the RNX ${ }^{\mathrm{TM}}$-Plus solution (CinnaGen, Iran) according to the manufacturer's instruction with a little modification. Briefly, in an RNAse-DNAse free $1.5 \mathrm{ml}$ eppendorf tube, $1 \mathrm{ml}$ of RNX ${ }^{\mathrm{TM}}$-Plus solution was added to $200 \mu \mathrm{l}$ of faecal sample. After shaking, $200 \mu \mathrm{l}$ of chloroform-isoamyl alcohol (24:1) was added and the mixture was centrifuged at $10,000 \mathrm{~g}$ at $4{ }^{\circ} \mathrm{C}$ for $15 \mathrm{~min}$. Equal volume of isopropanol was added to the upper phase in a new tube. The mixture was centrifuged at $12,000 \mathrm{~g}$ at $4{ }^{\circ} \mathrm{C}$ for $15 \mathrm{~min}$. The supernatant was discarded and $1 \mathrm{ml}$ of $75 \%$ ethanol was added to the pellet. After centrifugation at $4,000 \mathrm{~g}$ at $4{ }^{\circ} \mathrm{C}$ for $5 \mathrm{~min}$, the soup was discarded and the pellet was dried at room temperature for few minutes. Finally, the pellet was diluted in $20 \mu 1$ distilled water containing DEPC (diethyl pyrocarbonate) and quickly used in RT reaction.

RT reaction

For reverse transcription, $200 \mathrm{u}$ M-MVLV reverse transcriptase (Fermentas, Canada), $20 \mathrm{u}$ RNAse inhibitor (CinnaGen, Iran), $4 \mu \mathrm{l} 5 \times \mathrm{RT}$ buffer, $2 \mu 110 \mathrm{mM} \mathrm{dNTP}_{\mathrm{S}}, 2 \mu \mathrm{l}$ Uni-12 primer (20 pmol) and $5.5 \mu 1$ DEPC treated water, were added to $5 \mu \mathrm{l}$ RNA solution. The Uni-12 primer sequence was: $5^{/}$- AGC AAA AGC AGG -3/ (Peiris et al. 1999). The mixture was incubated at $43{ }^{\circ} \mathrm{C}$ for $1 \mathrm{~h}$ and then heated to $95{ }^{\circ} \mathrm{C}$ for 2 min and subsequently chilled on ice.

$\mathrm{PCR}$ reaction

For PCR, $1.25 \mathrm{u}$ Taq DNA polymerase (Cinnagen, Iran), $2.5 \mu 110 \times$ PCR buffer, $0.5 \mu 110 \mathrm{mM} \mathrm{dNTPs}, 1 \mu \mathrm{l}$ sense and antisense primers (each) $(10 \mathrm{pmol})$ and $16.5 \mu \mathrm{l}$ double distilled water were added to $2.5 \mathrm{ml} \mathrm{cDNA}$ mixture. The sequence of HA primers was: Sense 5/- TTG CAC CAC ACA GAG CAC AAT-3' and Antisense 5'TGA TGT ATG CCC CAC ATG AA-3' (Peiris et al. 1999).

The amplification protocol was: One step of denaturation at $95{ }^{\circ} \mathrm{C}$ for $2 \mathrm{~min}$, followed by 40 cycles of denaturation at $95{ }^{\circ} \mathrm{C}$ for $1 \mathrm{~min}$ - annealing at $50{ }^{\circ} \mathrm{C}$ for $1 \mathrm{~min}$ - extension at $72{ }^{\circ} \mathrm{C}$ for $1 \mathrm{~min}$, and one step of final extension at $72{ }^{\circ} \mathrm{C}$ for $10 \mathrm{~min}$. Samples with RNAse free sterile water instead of specific template used as negative controls and RNA extracted from the CAF containing challenge virus used as positive control. The 432bp product was detected by $1.5 \%$ agarose gel electrophoresis.

Analytical sensitivity and specificity of RT-PCR

The sensitivity of the RT-PCR assay was determined according to the standard method (Villegas 1998). Briefly, serial dilutions of the challenge virus in sterile PBS solution ranging from $10^{-1}$ to $10^{-9}$ were prepared and inoculated into 9-day-old embryonated chicken eggs. EID $_{50}$ titration was determined and all dilutions were examined by the RT-PCR assay for detection of AIV. To evaluate the specificity of the RT-PCR, allantoic fluids containing NDV (La Sota strain) and IBV (H120) were used.

\section{Results}

\section{Experimental infection}

HI test

All of the pre-inoculation serum samples obtained from test and control groups of chickens were AI antibody negative. Seroconversion was observed in the test group on day 7 and 14 p.i. In the control group, no seroconversion was observed on day 7 and 14 p.i. (Table 1).

Virus detection by virus isolation method

To evaluate AIV detection by VI method, faecal samples from 10 different birds/days in the test group were screened by VI assay. First positive samples were seen on day 2 p.i. and the last positive sample was detected on day 10 p.i. Most positive results were detected on days 3, 4, 5, 6 and 7 p.i. The percentage of positive samples to total ranged from 10 to $100 \%$ (Table 2). The faecal samples obtained from chickens of the control group, were all negative in VI method. 
Table 1. Avian influenza H9 serum antibody titration (Mean \pm SD) of the test and control groups of chickens experimentally infected with AI virus of A/Chicken/Iran/ZMT-101/98 (H9N2) strain related to the day post inoculation

\begin{tabular}{|c|c|c|c|}
\hline Day p.i & Day 0 p.i. & Day 7 p.i. & Day 14 p.i. \\
\hline Test & 0 & $5.4 \pm 0.8^{\mathrm{a}}$ & $6.6 \pm 1.3^{\mathrm{b}}$ \\
\hline Control & 0 & 0 & 0 \\
\hline
\end{tabular}

a) $\mathrm{CV}=15 \%$

b) $\mathrm{CV}=19.6 \%$

Table 2. AIV detection by virus isolation (VI) and RT-PCR in faecal samples of chickens experimentally infected with AI virus of A/Chicken/Iran/ZMT-101/98 (H9N2) strain related to the day post inoculation (p.i)

\begin{tabular}{|c|c|c|c|c|c|c|c|c|c|c|c|}
\hline $\begin{array}{c}\text { Day p.i } \\
\text { Test }\end{array}$ & 1 & 2 & 3 & 4 & 5 & 6 & 7 & 8 & 9 & 10 & Total \\
\hline VI & $0^{\mathrm{a} / 10^{\mathrm{b}}}$ & $1 / 10$ & $7 / 10$ & $7 / 10$ & $9 / 10$ & $10 / 10$ & $9 / 10$ & $4 / 10$ & $1 / 10$ & $1 / 10$ & $49 / 100(49 \%)$ \\
\hline RT-PCR & $0 / 10$ & $1 / 10$ & $6 / 10$ & $8 / 10$ & $10 / 10$ & $8 / 10$ & $6 / 10$ & $4 / 10$ & $3 / 10$ & $1 / 10$ & $47 / 100(47 \%)$ \\
\hline
\end{tabular}

a) number of positive samples

b) number of total samples

\section{Virus detection by RT-PCR method}

Faecal samples from 10 different birds/days in the test group were evaluated by RT-PCR assay, too. First positive samples were seen on day 2 p.i. and the last positive sample was detected on day 10 p.i. Most positive samples were detected on days 3, 5, 6 and 7 p.i. The percentage of positive samples to total ranged from 10 to $100 \%$ (Table 2). The faecal samples obtained from chickens of the control group, were all negative in RT-PCR method. The RT-PCR results of day 7 p.i. are shown (Fig. 1).

Field samples

VI was positive for 5 out of 30 samples. All AI isolates were typed as $\mathrm{H} 9$ by the HI test. By the RT-PCR, 6 out of 30 samples were positive.

Relative sensitivity, specificity and correlation rate, positive predictive value and negative predictive value of RT-PCR compared to VI

Experimental infection

A total number of 39 out of 100 samples were positive and 43 were negative with both RT-PCR and VI assays. Ten negative samples with RT-PCR were found positive with VI assay. Eight positive samples with RT-PCR were negative with VI assay (Table 3). None of the negative controls were positive. Chi-square test was used to compare the results of two tests, statistically. The relative specificity, sensitivity, correlation rate, positive predictive value and negative predictive value of RT-PCR compared with VI were $84 \%, 80 \%, 82 \%$, $83 \%$ and $81 \%$, respectively.

Table 3. Comparison between virus isolation (VI) and RT-PCR assays in faecal samples of chickens experimentally infected with AI virus of A/Chicken/Iran/ZMT-101/98 (H9N2) strain

\begin{tabular}{|c|c|c|c|}
\hline RI & Positive & Negative & Total RT-PCR samples \\
\hline Positive & 39 & 8 & 47 \\
\hline Negative & 10 & 43 & 53 \\
\hline Total VI samples & 49 & 51 & 100 \\
\hline
\end{tabular}

Field samples

A total number of 5 out of 30 samples were positive and 24 were negative with both RTPCR and VI assays. No negative sample with RT-PCR was found positive with VI assay 
but, one positive sample with RT-PCR was negative with VI assay (Table 4). The relative specificity, sensitivity, correlation rate, positive predictive value and negative predictive value of RT-PCR compared with VI were $96 \%, 100 \%, 97 \%, 83 \%$ and $100 \%$, respectively.

Table 4. Comparison between virus isolation (VI) and RT-PCR assays, in field samples collected from flocks suspected to AI

\begin{tabular}{|c|c|c|c|}
\hline RT-PCR & Positive & Negative & Total RT-PCR samples \\
\hline Positive & 5 & 1 & 6 \\
\hline Negative & 0 & 24 & 24 \\
\hline Total VI samples & 5 & 25 & 30 \\
\hline
\end{tabular}

Analytical sensitivity and specificity of RT-PCR

The detection limit of the RT-PCR was determined to be approximately equivalent to $10^{3.5}$ EID $_{50}$. The RT-PCR did not cross-amplify Newcastle disease virus (La Sota) and infectious bronchitis virus (H120) strains.

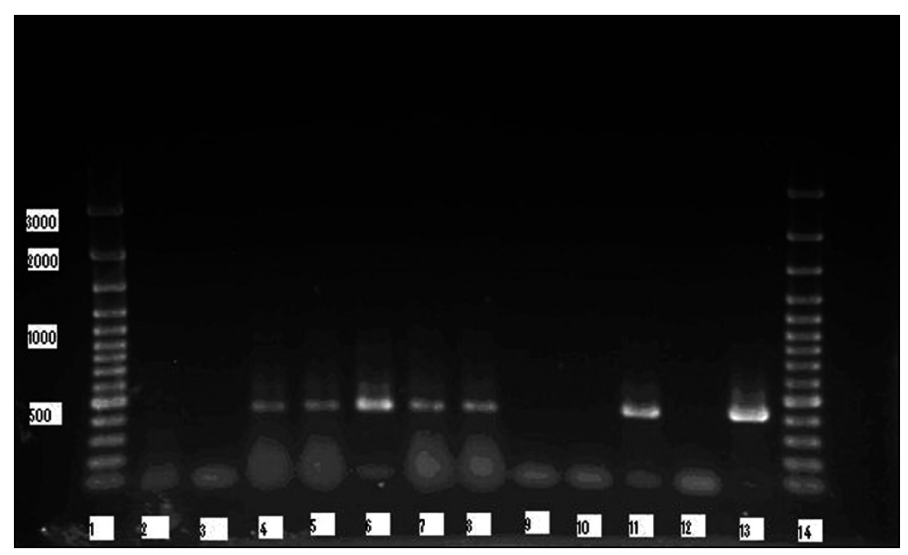

Fig. 1. The RT-PCR results of 10 faecal swabs collected at day 7 post inoculation from chickens infected with AI virus of A/Chicken/Iran/ZMT-101/98 (H9N2) strain. Lanes 1 and 14, 100bp marker; lanes 2-11, faecal samples from chickens of numbers 1-10, respectively; lane 12, negative control and lane 13, positive control.

\section{Discussion}

RT-PCR method has previously been used to detect influenza A virus in throat and nasal specimens collected from humans, pigs and horses (Claas et al. 1993; Oxburgh et al. 1999; Schorr et al. 1994; Yamada et al. 1991) and to detect avian respiratory viruses in clinical specimens (Fouchier et al. 2000; Gohm et al. 2000; Handberg et al. 1999; Munch et al. 2001; Starick et al. 2000).

Gohm et al. (2000) reported that Newcastle disease virus (NDV) in clinical samples from experimentally and contact-infected chickens could be quickly, easily and reliably detected by the RT-PCR assay until the end of the experiment (day 28 p.i.) in caecal tonsils, kidneys and faecal samples and NDV detection by RT-PCR lasted longer after infection than by VI using embryonated eggs. They suggested that RT-PCR is more sensitive than VI to detect NDV neutralized by specific antibodies. In the study of Gohm et al. (2000), the RT-PCR assay results of proventriculus and intestine were negative, although faecal samples were positive at the same time. It is suggested that faecal sample is a homogenate 
in itself and can be used for RNA extraction of viruses excreted in faeces, without further processing. It is possible that only distinct parts of the intestinal tract contain faecal excreted viruses at a given time, and therefore faecal samples passed through the whole intestine can be enriched with high amounts of the viruses. Furthermore, the viruses originating from kidneys are also excreted in faeces. Also, because of a high bacterial load and toxic substances, it is sometimes difficult to perform virus detection in faeces by VI (Gohm et al. 2000). Therefore, RT-PCR could be a valuable alternative test.

Results of comparison of RT-PCR and IHC (Immunohistochemistry) assays showed that RT-PCR could detect infectious bronchitis virus (IBV) in $82 \%$ of the samples collected up to 3 days p.i. from chickens experimentally infected with IBV reference strains, while the corresponding figure for IHC was $60 \%$. There was a good correlation between the results of the two techniques, although the sensitivity of the RT-PCR assay was greater than IHC (Handberg et al. 1999).

Hermann et al. (2001) developed a nested multiplex RT-PCR for simultaneous detection and typing of influenza A. Target sequences were located in the HA gene. The efficiency of the RT-PCR assay was evaluated by comparing the results with VI on clinical specimens collected from influenza suspected patients. Sensitivity and specificity of the RT-PCR compared with VI were $95.4 \%$ and $86.6 \%$, respectively. The detection rate of this nested multiplex RT-PCR assay was clearly higher than was found in another HA gene-nested multiplex RT-PCR (Magnard et al. 1999), but lower than reported from a study using matrix gene as the target (Wallace et al. 1999). These results suggest that the type of the target gene and length of the amplified segment may affect the sensitivity of RT-PCR.

Atmar et al. (1996) applied a RT-PCR assay for detection of influenza A virus on clinical specimens. Compared with VI, the RT-PCR assay had a sensitivity, specificity and efficiency of $95 \%, 98 \%$ and $97 \%$, respectively. These results were better than one of the best commercially available diagnostic kit (Directigen ${ }^{\circledR}$, Becton Dickson).

Cattoli et al. (2004) compared RT-PCR and Directigen ${ }^{\circledR}$ diagnostic kit with VI on specimens collected from experimentally infected birds and indicated that VI assay could detect infectious virus in the tracheal swabs of the infected turkeys from day 3 to 10 post challenge, Directigen ${ }^{\circledR}$ diagnostic kit from day 5 to 10 post challenge, and RT-PCR from day 3 to 12 post challenge. In field samples obtained from naturally infected poultry flocks, the relative sensitivity, specificity and correlation rate of the RT-PCR assay compared to VI were $95.6 \%, 96.3 \%$ and $88 \%$, respectively. Overall, there was a good correlation between the results of the three tests (Cattoli et al. 2004).

Some researchers have reported that RT-PCR results did not correlate as well with VI, as some samples were positive by only one method. Munch et al. (2001) and Spackman et al. (2002) reported that the differences in the detection of AIV between VI and RT-PCR assays can probably be explained, at least in part, by what the assays are detecting. RT-PCR, in contrast to VI, is able to detect viruses inactivated during transfer or by disinfectants present in environmental samples. It was estimated that non-infectious particles constitute as much as $90 \%$ of some virus preparation (Hirst et al. 1973). Additionally, all influenza virus isolates may not be readily adapted and replicated to detectable titres in embryonated chicken eggs within two passages (Spackman et al. 2002). Also, false positive results due to cross contamination can cause some samples to be RT-PCR positive and VI negative (Hermann et al. 2001).

Conversely, some factors may adversely affect the sensitivity of RT-PCR versus VI and inhibit detecting the presence of AIV. Koch (2003) and Wilde et al. (1990) reported RTPCR inhibitory substances in some tissue or faecal samples. Single step RT-PCR method is supposed to be less sensitive than a two-step RT-PCR method (Nakamura et al. 1993).

In the field studies, swab samples are generally taken from living birds and organ samples are taken from dead birds. Extracted RNA may be degraded more rapidly in organ samples 
containing higher levels of RNAse, so that swab samples may generally yield better results. Alternatively, choosing a suitable RNA extraction method could assure the extraction of pure RNA (Spackman et al. 2002) and decrease the risk of RNA degradation (Horimoto and Kawaoka 1995).

The sensitivity and specificity of PCR-based methods are most critically determined by the choice of primers (Fouchier et al. 2000), particularly for the surface glycoprotein genes of AI viruses which have a high frequency of variations (Swayne et al. 2003). Negative and positive controls should be included in the RT-PCR protocol to refuse the possibility of false results (Gohm et al. 2000; Hermann et al. 2001). The primers used in the present study had been chosen from highly conserved area of the viral HA gene. These primers had successfully amplified mammalian and avian H9N2 isolates and had not crossamplified any other human or avian influenza viruses of $\mathrm{H}$ subtypes as reported by Peiris et al. (2003). The sequence of this specific primer set was evaluated by BLAST software in order to assure its annealing efficiency.

Regardless of the method chosen for sensitivity determination, it is difficult to ascertain the minimum number of target viruses needed for a detectable PCR product (Hermann et al. 2001). We recorded a lower analytical sensitivity $\left(10^{3.5} \mathrm{EID}_{50}\right)$ for the RT-PCR compared with other reports (Cattoli et al. 2004; Fouchier et al. 2000; Hermann et al. 2001). This might be due to the different materials and protocols applied in the present study, to different virus strain and subtype tested or to the nature and quality of the samples.

The recorded relative sensitivity, specificity and correlation rate of the RT-PCR on faecal samples of experimentally infected chickens in the present study were somewhat lesser than those of similar reports (Atmar et al. 1996; Boivin et al. 2001; Cattoli et al. 2004; Hermann et al. 2001; Steininger et al. 2002; Taubenberger et al. 2001). On the field samples, better relative sensitivity and specificity have been reported. It is suggested that the birds submitted for necropsy to a diagnostic laboratory, usually represent birds with the most clinical signs and presumably with the most virus shedding. In contrast, the testing of every bird in an animal experiment does not skew samples toward birds with the most viruses (Woolcock et al. 2005).

The true specificity of the RT-PCR in the present study and similar reports is probably higher than observed. This could be related to a loss of viability of the virus during sample transfer or storage. Serological evidences can confirm if one case or flock detected positive by RT-PCR and negative by VI has been truly infected. Some other assays, such as the sequencing of the amplified product, restriction fragment length polymorphism (RFLP) and hybridization can confirm the RT-PCR results.

In conclusion, the RT-PCR assay reported in this study can be used for simultaneous detection and subtyping of AIV of $\mathrm{H} 9$ subtype in a faecal sample as a rapid, sensitive and specific alternative to VI. This assay may be a reliable method for screening AI infected live domestic or wild birds and monitoring commercial flock to detect H9 subtype in early stages of infection. However, monitoring HA gene sequence of new H9 isolates for the detection of probable genetic variations in the primers annealing sites is essential to assure the satisfactory efficiency of the RT-PCR in detection of new isolates.

\section{Detekce subtypu H9 viru aviární influenzy ve fécés experimentálně a přirozeně infikovaných kuřat pomocí RT-PCR}

Aviární influenza (AI) je vysoce kontagiózní virové onemocnění domácích a divokých ptáků. V diagnostické laboratoři onemocnění ptáků je nezbytné mít $\mathrm{k}$ dispozici testy rychlé detekce virů dýchacího aparátu. V této studii byly prováděny kloakální výtěry u kuřat experimentálně a přirozeně infikovaných slabě patogenním subtypem H9 viru AI, 
ten byl pak detekován pomocí RT-PCR (reverse transcription-polymerase chain reaction nebo reverzní transkriptázová-polymerázová řetězová reakce, ale spíš se to nepřekládá). V kloakálních výtěrech experimentálně infikovaných kuřat byl virus AI detekován nejčastěji mezi 3. až 7. dnem po infekci (p.i.). Relativní senzitivita, specificita, prevalence, pozitivní prognostická hodnota a negativní prognostická hodnota. RT-PCR u těchto kuřat byly v porovnání s izolací viru (VI) 84\%, 80\%, 82\%, 83\% a 81\%. Ve směsných vzorcích kloakálních výtěrů hejn podezřelých z nákazy AI byly tyto hodnoty $96 \%, 100 \%, 97 \%, 83 \%$ a 100\%. Výsledky ukázaly, že RT-PCR by mohla být spolehlivá a rychlá alternativa izolace viru pro detekci subtypu H9 viru AI ve vzorcích fécés.

\section{Acknowledgements}

This research was supported by a grant No 7508001.6.1. from the Research Deputy of Faculty of Veterinary Medicine, University of Tehran. Also, the authors are grateful to Department of Clinical Science, Poultry Diseases Section (Tehran, Iran).

\section{References}

ALDOUS EW, ALEXANDER DJ 2001: Detection and differentiation of Newcastle disease virus (avian paramyxovirus type 1). Avian Pathol 30: 117-128

ALLWINN R, PREISER W, RABENAU H, BURBAUM S, STURMER M, DOERR HW 2002: Laboratory diagnosis of influenza - virology or serology? Med Microbiol Immunol 191: 157-160

ATMAR RL, BAXTER BD, DOMINGUEZ EA, TABER LH 1996: Comparison of reverse transcription-PCR with tissue culture and other rapid diagnostic assays for detection of type A Influenza virus. J Clin Microbiol 34: $2604-2606$

BOIVIN G, LARDY L, KRESS A 2001: Evaluation of a rapid optical immunoassay for influenza viruses (FLU OIA test) in comparison with cell culture and reverse transcription-PCR. J Clin Microbiol 39: 730-732

BOOTH S, BALERIOLA C, RAWLINSON WD 2006: Comparison of two rapid influenza A/B test kits with reference methods showing high specificity and sensitivity for influenza A infection. J Med Virol 78: 619-622

CATTOLI G, DRAGO A, MANIERO S, TOFFAN A, BERTOLI E, FASSINA S, TERREGINO C, ROBBI C, VICENZONI G, CAPPUA I 2004: Comparison of three rapid detection systems for type A Influenza virus on tracheal swabs of experimentally and naturally infected birds. Avian Pathol 33: 432-437

CLAAS ECJ, VAN MILAAN AJ, SPRENGER MJW, RUITEN-STUIVER M, ARRON GI, ROTHBRATH PH, MASUREL N 1993: Prospective application of reverse transcriptase polymerase chain reaction for diagnosis influenza reactions in respiratory samples from children's hospital. J Clin Microbiol 162: 2218-2221

DAVISON S, ZIEGLER AF, ECKROADE RJ 1998: Comparison of an antigen-capture enzyme immunoassay with virus isolation for avian Influenza from field samples. Avian Dis 47: 791-795

DOMINGUEZ EA, TABER LH, COUCH RB 1993: Comparison of rapid diagnostic techniques for respiratory syncytial and influenza A virus respiratory infections in young children. J Clin Microbiol 31: 2286-2290

FEDORKO DP, NELSON NA, MCAULIFFE JM, SUBBARAO K 2006: Performance of rapid tests for detection of avian influenza A virus type H5N1 and H9N2. J Clin Microbiol 44: 1596-1597

FOUCHIER RAM, BESTEBROER TM, HERFST S, KEMP LVD, RIMMELZWAAN GF, OSTERHAUS ADME 2000: Detection of influenza A viruses from different species by PCR amplification of conserved sequences in the matrix gene. J Clin Microbiol 38: 4096-4101

GAVIN PJ, THOMSON RB 2003: Review of rapid Diagnostic tests for Influenza. Clin Appl Immunol Rev 4: 151-172

GOHM DS, THUR B, HOFMANN MA 2000: Detection of Newcastle disease virus in organs and feces of experimentally infected chickens using RT-PCR. Avian Pathol 29: 143-152

HANDBERG KJ, NIELSEN OL, PEDERSEN MW, JORGENSON PH 1999: Detection and strain differentiation of infectious bronchitis virus in tracheal tissues from experimentally infected chickens by reverse transcriptionpolymerase chain reaction. Comparison with an immunohistochemical technique. Avian Pathol 28: 327-335

HERMANN B, LARSSON C, ZWEYGBERG BW 2001: Simultaneous detection and typing of Influenza $\mathrm{A}$ and $\mathrm{B}$ by a nested reverse transcription-PCR: comparison to virus isolation and antigen detection by immunofluorescence and optical immunoassay (FLU OIA). J Clin Microbiol 39: 134-138

HIRST G, PONS M 1973: Mechanism of influenza recombination. II. Virus aggregation and its effects on plaque formation by so-called non-infective virus. Virology 56: 620-631

HORIMOTO T, KAWAOKA Y 1995: Direct reverse transcription PCR to determine virulence potential of influenza A viruses in birds. J Clin Microbiol 33: 748-751

KOCH G 2003: Laboratory issues: Assessment of the sensitivity and specificity of PCR for NDV of cloacal and tracheal swabs compared to virus isolation. Proceedings of the joint seventh annual meetings of the national Newcastle disease and avian influenza laboratories of countries of the European union, Padova, Italy, 2002, pp.114-117 
LIU J, OKAZAKI K, SHI W, WU Q, MWEEN AS, KIDA H 2003: Phylogenetic analysis of neuraminidase gene of H9N2 Influenza viruses prevalent in chickens in China during 1995 - 2002. Virus Genes 27:197-202

MAGNARD C, VALETTE M, AYMARD M, LINA B 1999: Comparison of two nested PCR, cell culture and antigen detection for the diagnosis of upper respiratory tract infections due to Influenza viruses. J Med Virol 59: $215-220$

MUNCH M, NIELSEN LP, HANDBERG KJ, JORGENSEN PH 2001: Detection and subtyping (H5 and H7) of avian type A Influenza virus by reverse transcription-PCR and PCR-ELISA. Arch Virol 146: 87-97

MURPHY FA, GIBBS EPJ, HORZINEK MC, STUDDERT MJ 1999: Veterinary Virology (3rd ed.). California, Academic Press, USA, pp. 466-468

NAKAMURA S, KATAMINE S, YAMAMOTO T, FONG S, KURATA T, HIRABAYASHI Y, SHIMADA K, HINO S, MIYAMOTO T 1993: Amplification and detection of a single molecule of human immunodeficiency virus RNA. Virus Genes 4: 325-338

NILI H, ASASI K 2003: Avian influenza (H9N2) outbreak in Iran. Avian Dis 47: 828-31

OIE Standard Commission 2004: Manual of diagnostic tests and vaccines for terrestrial animals (5th ed.), OIE Publication, Chapter 2.1.14.

OXBURGH L, HAGSTROM A 1999: A PCR based method for the identification of equine influenza virus from clinical samples. Vet Microbiol 67: 161-174

PEIRIS M, YAM WC, CHAN KH, GHOSE P, SHORTRIDGE KF 1999: Influenza A H9N2: aspects of laboratory diagnosis. J Clin Microbiol 37: 3426-3427

RYAN-POIRIER K, KATZ JM, WEBSTER RG, KAWAOKA Y 1992: Application of Directigen FLU-A for the detection of Influenza A virus in human and nonhuman specimens. J Clin Microbiol 30: 1072-1075

SCHORR E, WENTWORTH D, HINSHAW VS 1994: Use of polymerase chain reaction to detect swine influenza virus in nasal swab specimens. Am J Vet Res 55: 952-956

SENNE DA 1998: Virus propagation in embryonating eggs. In: SWAYNE DE, GLISSON JR, JACKWOOD MW, PEARSON JE, REED WM (Eds): Isolation and Identification of Avian Pathogens (4th ed.). American Association of Avian Pathologists, University of Pennsylvania, USA, pp. 235-240

SPACKMAN E, SENNE DA, MYERS TJ, BULAGA LL, GARBER LP, PERDUE ML, LOHMAN K, DAUM LT, SUAREZ DL 2002: Development of a real time reverse transcription PCR assay for type A Influenza virus and the avian $\mathrm{H} 5$ and $\mathrm{H} 7$ haemaggluttinin subtypes. J Clin Microbiol 40: 3256-3260

STARICK E, ROMER-OBERDORFER A, WERNER O 2000: Type- and subtype- specific RT-PCR assays for avian influenza viruses (AIV). J Vet Med B-Infect Dis Vet P 47: 295-301

STEININGER C, KUNDI M, ABERLE SW, ABERLE JH, POPW-KRAUPP T 2002: Effectiveness of reverse transcription-PCR, virus isolation and enzyme-linked immunosorbent assay for diagnosis of Influenza A virus infection in different age groups. J Clin Microbiol 40: 2051-2056

SWAYNE DE, HALVORSON DA 2003: Influenza. In: SAIF YM, BARNES HJ, GLISSON JR, FADLY AM, MCDOUGALD LR, SWAYNE DE (Eds): Diseases of Poultry, (11 ${ }^{\text {th }}$ ed.). American Association of Avian Pathologists, Iowa State University Press, Iowa, USA, pp.135-160

TAUBENBERGER JK, LAYNE SP 2001: Diagnosis of Influenza Virus: coming to grips with the molecular era. Mol Diagn 6: 201-205

VASFI MARANDI M, BOZORGMEHRI FARD MH 1999: An outbreak of non-highly pathogenic avian Influenza in chickens in Iran. Proceedings of the $61^{\text {st }}$ meeting of the World Veterinary Association. Lyon, France

VASFI MARANDI M, BOZORGMEHRI FARD MH 2001: Preparation and evaluation of an inactivated H9N2 avian influenza antigen for using in haemagglutination inhibition test. Iranian J Vet Res 2: 174-181

VILLEGAS P 1998: Titration of biological suspensions. In: SWAYNE DE, GLISSON JR, JACKWOOD MW, PEARSON JE, REED WM (Eds): Isolation and Identification of Avian Pathogens (4 ${ }^{\text {th }}$ ed.). American Association of Avian Pathologists, University of Pennsylvania, USA, pp. 235-240

WALLACE LA, MCAULAY KA, DOUGLAS JD, ELDER AG, STOTT DJ, CARMAN WF 1999: Influenza diagnosis: form dark isolation into the molecular light, West of Scotland Respiratory Virus Study Group. J Infect 39: 221-226

WANER JL, TODD SJ, SHALABY H, MURPHY P, WALL LV 1991: Comparison of Directigen FLU-A with viral rapid isolation and direct immunofluorescence for the rapid detection and identification of influenza $\mathrm{A}$ virus. J Clin Microbiol 29: 479-482

WILDE J, EIDEN J, YOLKEN R 1990: Removal of inhibitory substances from human fecal specimens for detection of group A rotaviruses by reverse transcriptase and PCR. J Clin Microbiol 28: 1300-1307

WOOLCOCK PR, CARDONA CJ 2005: Commercial immunoassay kits for the detection of influenza virus type A: evaluations of their use with poultry. Avian Dis 49: 477-481

YAMADA A, IMANISHI J., NAKAJIMA K, NAKAJIMA S 1991: Detection of influenza viruses in throat swab by using polymerase chain reaction. Microbiol Immunol 35: 259-265 